\title{
A REVIEW ON INVENTORY MANAGEMENT SYSTEM AT MANUFACTURING ORGANIZATION
}

\author{
Priti Singh \\ Department of Mechanical Engineering \\ Babulal Tarabai Institute of Research and Technology \\ Sironja, Sagar, Madhya Pradesh, India
}

\begin{abstract}
Now a day inventory of material is most important part of any organization. Inventory management system is a system for tracking inventory levels, order, sales and deliveries. Inventory control means the availability of right materials of right quantities. It is a tool for organizing inventory data that before was generally stored in hard copy form or in spreadsheets. Every component of inventory is significant and it is essential to manage the inventories. Inventory management system is made up of several key components such as - Reorder Point, Asset tracking, service management, Product identification and Inventory optimization. The manufacturing company is having definite policies for control and supervision of the inventory, but it requires a throughout study of their guiding principles and systems to a great extent to be acquainted with the inventory management. The manufacturing organizations often use inventory $A$ management system to reduce their carrying costs. This facilitates the manufacturing process by helping manufacturers efficiently assemble the tools and parts they need to perform specific tasks. In this paper we study the different researcher's papers and find out the best $B$. methods and process to control the inventory of manufacturing organization to reduce the carrying costs and variable costs of products.
\end{abstract}

Keywords - Inventory, Inventory Control, ABC analysis, Economic Order Quantity, Reorder Point, Carrying Cost

\section{INTRODUCTION}

In the today scenario non availability of a single material, which contributes production, not even $1 \%$ will create critical situation, which may stop the production or finished goods movement in any industry. The financial point of view inventory is the single largest asset in the balance sheet in many manufacturing companies. it is absolutely necessary rather a must, to control the inventory for not only effective management of working capital but also for smooth production and to cut the cost of interest so as to sustain and survive in business especially in today's era of cutthroat

\author{
Tarun Kumar Yadav \\ Department of Mechanical Engineering \\ Babulal Tarabai Institute of Research and Technology \\ Sironja, Sagar, Madhya Pradesh, India
}

competition. Thus managing inventory into an optimum level is all the more important which result in cost reduction, efficient use of working capital and improved earnings.

In today's Industrial climate, multinational corporations are entering into all fields of Business that too, in auto industries. This Situation leads to heavy Competition among the Industries in the same field.

"Uncontrolled Inventory Is the Industry's Cancer" is the wellknown slogan. If the inventories are not controlled effectively it will create many problems in the industry. So there is a need for every company to control its inventory in all stages.

CONCEPTS OF INVENTORY - Inventory can be broadly defined as the stock of goods, commodities or other economic resources that are stored or reserved at any given period for future production or for meeting future demands.

\section{NEED FOR INVENTORY CONTROL}

(i). Effect of Control at Raw Material

(ii). Effect of Control at Finished Goods

(iii). Effect of Uncontrolled of Other Inventories

\section{CLASSIFICATION OF INVENTORY}

(i). Direct Inventories

a) Raw Material Inventories

b) Work in Process Inventories

c) Finished Goods Inventories

(ii). Indirect Inventories

$$
\text { Inventory Control }
$$




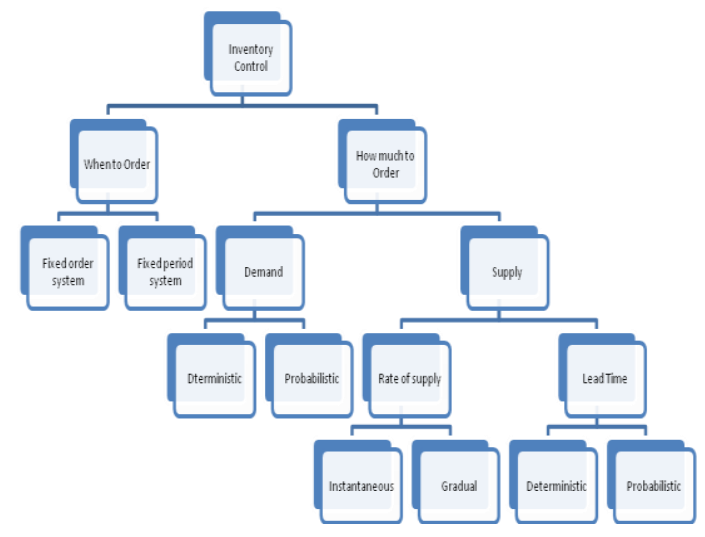

Figure 1. Inventory Control

\section{OBJECTIVE OF STUDY}

\section{A. PRIMARY OBJECTIVE}

Overall, the Primary Objective is to minimize the investment in inventories by excising selective inventory control techniques.

\section{B. SECONDARY OBJECTIVE}

1. To study and analyze the performance of inventory management of manufacturing origination.

2. To review the system of inventory model and reorder level of raw material.

2. To find out the economic order quantity for cutting tools and consumables.

4. To determine the optimum level of safety stock for cutting tools and Consumables and to fix reorder point

\section{EFFORTS BY VARIOUS RESEARCHERS}

[1] Lieberman et. al. (1999) in his article titled "Inventory reduction and productivity growth: Linkages in the Japanese automotive industry" published in Management Science has said that JIT production suggests a causal link between workin-progress inventory and manufacturing productivity. Such a connection has been described in numerous case studies but never tested statistically. Historical data for 52 Japanese automotive companies are used to evaluate the inventoryproductivity relationship. It is found that firms increased their productivity rank during periods of substantial inventory reduction. More detailed tests suggest that inventory reductions stimulated gains in productivity.

[2] Moon and Ilkyeong (2001) The authors Moon \& Ilkyeong published their paper in Interfaces titled "Inventory Management and Production Planning and Scheduling" which is the third version of Decision Techniques for Stock Control and Manufacturing Preparing released in 1979 and 1985. Bobpyke became a coauthor for this version and performed a key part in composing significant updates of several sections, such as those on supply-chain management, multiechelon stocks, just in time, and ERP (enterprise source planning). In addition, the writers have included worksheet applications for each section as additional components to improve the audience and usefulness for learners in business applications, and for experts.

[3] Jackson and Duncan (2004) as per the author, "Trade Beam and Global exchange Services Partner to Provide Collaborative Inventory Management and Interoperability for Automotive Industry", in Business Wire says that Trade Beam is a Global Trade Management software and services company providing solutions that streamline global trading processes for enterprises and their partners. Trade Beam's solutions provide import and export compliance, inventory management, shipment tracking, supply chain event management and global trade finance solutions such as open account and letter of credit management. Trade Beam has over 3000 customers with users in over 100 countries worldwide.

[4] Krishna et. al. (2009) in their article "Web Integrated Decision Support System for Machine Scheduling and Inventory Management", was published in IUP Journal of Operations Management tells about stock management symbolizes the process of managing stocks of completed products, semi-finished products and raw elements by a company so as to reduce the total stock cost. The first level contains the development of a organizing program with make span minimization as the primary objective. The second level contains the development of the stock management program and creating it with the organizing program. The third level contains creating the program web permitted, so that it provides the flexibility of assigned creating choices to your selection makers.

[5] Snehalgavi (2010) According to her article titled "It Outsourcing in Indian Automobile Industry" in Business \& Economy says Outsourcing is the act of delegating an organization's internal activities and to some extent the right to decisions to the third party (service vendors) as per specified in the contract. Outsourcing is a tool, in which the vendor is responsible for certain jobs outsourced by a company, in return of a price for the goods or service provided by it. This option is exercised majorly because to cut operation costs of a company and focus on its core competencies. It is basically a contract between two companies or concern in which one is getting its business process outsourced from another company offering such services.

[6] Martin and Benjamin Robert (2010) in his article titled "Findlay Automotive group selects first look for pre- owned inventory management needs", in PR Newswire With 15 brands including Toyota, Honda, Chevrolet, Cadillac, Saturn, Land Rover, Saab and Volkswagen, Findlay will utilize the First Look product suite to guarantee the right balance 


\section{International Journal of Engineering Applied Sciences and Technology, 2019 \\ Vol. 4, Issue 6, ISSN No. 2455-2143, Pages 121-126 \\ Published Online October 2019 in IJEAST (http://www.ijeast.com)}

between pre-owned inventory and demand, and ensure that trades are given the best appraisals.

In addition to the inventory management tool, and trade analyzer, Findlay will use the First Look Search Engine to allow its dealers to instantly search more than 30 online marketplaces to identify the best vehicles that meet that dealerships pre-owned inventory needs.

[7] Koumanakos and Dimitrios P. (2008) in Business Wire titled "Hitachi Automotive Improves Efficiency and Inventory Control with Geac's System 21" says that Hitachi America, Ltd. has streamlined production, reduced accounting costs and improved supply chain management using Geac's System 21 software solution. Hitachi Automotive implemented three System 21 modules in 1998 - financials, manufacturing, and customer service and logistics - across its three locations in Kentucky, Detroit and Los Angeles. In September 2002,the company will renew its maintenance contract with $\mathrm{Geac}(\mathrm{R})$ for three years.

[8] Cachon et. al. (2010), "Drivers of Finished-Goods Inventory in the U.S. Automobile Industry", in Management Science says Automobile manufacturers in the U.S. supply chain exhibit significant differences in their days of supply of finished vehicles. The objective in this research is to measure for this industry the effect of several factors on inventory holdings. We find that two factors, the number of dealerships in a manufacturer's distribution network and a manufacturer's production flexibility, explain essentially all of the difference in finished-goods inventory between Toyota and three other manufacturers: Chrysler, Ford, and General Motors.

[9] Moozakis and Chuck (2001), "Honda Automates Web Financing -- Network will let dealers apply for funds online and will eventually support inventory management" in Internet Week says that financing unit of American Honda Motor Co. next month will begin rolling out its Dealer Financial Information Network (DFIN), a Web system that will help its 3,000 dealers obtain financing for inventory in real time. Currently,dealers purchasing inventory from Honda need to apply for financing through American Honda Finance Corp. or another bank. Typically, approvals take several days.

[10] Borade et. al. (2010) in this paper authors says that, the global economy, vendor-managed inventory (VMI) is gradually becoming an important element of supply chain management strategy of organizations. Recently, Indian industries, both large and small, have started adopting VMI for their supply chains. The purpose of this paper is to investigate apparent differences among large and small industries in terms of objectives, drivers, obstacles and impacts of VMI in Indian context. A survey was conducted to examine organizational objectives, strategic drivers, obstacles and affected operations pursuant to VMI adoption.

[11] Matson et. al. (2007), in "Just-in-time implementation issues among automotive suppliers in the southern USA" published in Supply Chain Management speaks that Purpose The purpose of this paper is to provide insight into the major supply chain issues of the automotive manufacturing industry in the southern USA. Design/methodology/approach - This paper is based on the results of a survey of automotive suppliers in Tennessee and Alabama. The survey focused on supply chain issues and demographics, specifically on 20 JITrelated problems and 100 company characteristics. Findings Identifies the extent of JIT implementation in Tennessee's and Alabama's growing automotive industry and the general characteristics of the companies that use JIT.

\section{PROPOSED METHODOLOGY}

This chapter deals with the methodology adopted for the project. Both primary and secondary data were used for the preparation of project.

There are three basic types of inventory: raw materials, workin-progress and finished goods. Raw materials are the items purchased by firms for use in production of finished product. Work-in-progress consists of all items currently in the process of production. These are actually partly manufactured products. Finished goods are goods that have completed the manufacturing process but have not yet been sold or distributed to the end user. Inventory constitutes one of the important items of current assets, which permits smooth operation of production and sale process of a firm. Inventory management is that aspect of current assets management, which is concerned with maintaining optimum investment in inventory and applying effective control system so as to minimize the total inventory cost.

A. Research Variables

(i) To find out the cost involved in the entire inventory management process.

(ii) To ensure that the supply of raw material \& finished goods will remain continuous so that production process is not halted and demands of customers are duly met.

(iii) To minimize carrying cost of inventory.

(iv) To keep investment in inventory at optimum level.

(v) To reduce the losses of theft, obsolescence \& wastage etc.

(vi) To minimize inventory ordering costs.

B. General Problems of Inventory

(i) To maintain only a minimum possible inventory because of inventory holding cost and opportunity cost of funds invested in inventory.

(ii) Control investment in inventories and keep it at the optimum level.

(iii) To maintain a large size inventories for efficient and smooth production and sales operation.

C. Collection of primary data

The researcher approaches various functional heads in charge of materials, production, finance and marketing and collected related information for the study. The data was collected by 


\section{International Journal of Engineering Applied Sciences and Technology, 2019 \\ Vol. 4, Issue 6, ISSN No. 2455-2143, Pages 121-126 \\ Published Online October 2019 in IJEAST (http://www.ijeast.com)}

the researcher based on observation technique personally. The researcher has done physical inspection of stores and stock levels.

\section{Collection of secondary data}

1. Data for the previous year was obtained from the records of the company.

2. The stores of Manufacturing organization consists various inventories of raw materials, consumables, spares packing material etc. the range of inventories are vide and consists about more than thousand items. Hence, the focus was turned mainly to consumables and raw materials. The elements were selected after considering its usage value, importance and contribution towards production.

\section{TOOL FOR ANALYSIS}

\section{RATIO ANALYSIS}

\section{Operating Cycle Analysis}

\section{ABC Analysis}

Graphical representations like bar chart, trend chart, pie chart were used for simple understanding.[2]

\section{PROPOSED WORK}

From the above discussions it seems that it has now become necessary to apply the Inventory Management for material control in SME's. The proposed research work aims at careful study and development of existing technique using the inventory control for a SME.

\section{CONCLUSION}

We know the inventory of materials plays vital role in the management of working capital in any manufacturing organization. Inventory can be broadly defined as the stock of goods, commodities or other economic resources that are stored or reserved at any given period for future production or for meeting future demands. After the study we conclude that the effectiveness of inventory management would be improved in all the aspects hence the inventory can still strengthen its position by looking the given suggestion.

It conclude that the manufacturing organization used to Justin- Time, ERP, global trading process, Stream lined production, proper identified the no. of dealership distribution network and Vendor managed inventory (VMI) technique used productivity increased to reduce the inventory.

\section{REFERENCE}

[1]. B. Lieberman, Marvin B; Demeester, Lieven (1999), "Inventory reduction and productivity growth:
Linkages in the Japanese automotive industry", Management Science (45.4).

[2]. Moon, Ilkyeong (2001), "Inventory Management and Production Planning and Scheduling", Interfaces ( 31.6), Pg.-125-127.

[3]. Jackson, Duncan (2004), "TradeBeam and Global eXchange Services Partner to Provide Collaborative Inventory Management and Interoperability for Automotive Industry", Business Wire.

[4]. Krishna, L Sivarama; Janardhan, G Ranga; Rao, C S P (2009), "Web Integrated Decision Support System for Machine Scheduling and Inventory Management", IUP Journal of Operations Management (8.1), Pg.- 35-52.

[5]. Snehalgavi (2010), "It Outsourcing in Indian Automobile Industry", Business \& Economy.

[6]. Martin, Benjamin Robert (2010), "Findlay Automotive group selects first look for pre- owned inventory management needs", PR Newswire

[7]. Koumanakos, Dimitrios P. (2008), "Hitachi Automotive Improves Efficiency and Inventory Control with Geac's System21", Business Wire.

[8]. Cachon, Gérard P; Olivares, Marcelo (2010), "Drivers of Finished-Goods Inventory in the U.S. Automobile Industry", Management Science.

[9]. Moozakis, Chuck (2001), "Honda Automates Web Financing -- Network will let dealers apply for funds online and will eventually support inventory management", Internet Week 850.

[10]. Borade, Atul B; Bansod, Satish V. (2010), "Study of vendor-managed inventory practices in Indian industries", Journal of Manufacturing Technology Management (21.8), Pg.- 1013-1038.

[11]. El-Khalil, Raed; Farah, Maya F (2013), "Lean Management Adoption Level in Middle Eastern Manufacturing Facilities", Business Review Cambridge 21.2, Pg.- 158- 167.

[12]. New and Payne 1995, "Research frameworks in Logistics: three models, seven dinners and a survey, International Journal of Physical Distribution and Logistics Management".

[13]. Council of Logistics Management, 2001 extracted from "What its All About"

[14]. Tan, Choon Kean, 2001, "A framework of supply chain management literature" European Journal of Purchasing and Supply Management

[15]. Farmer, 1997, "Purchasing myopia-revisited", European Journal of Purchasing and Supply Management

[16]. Fisher 1997 "What is the right supply chain for your product?" Harvard Business Review, 75

[17]. Fredendall and Hill, 2001 Basics of Supply Chain Management, St. Lucie Press

[18]. Frazelle, 2001, World Class Warehousing and Material Handling, The McGraw Hill Companies 
[19]. Liberatore, 1979, "The EOQ Model under Stochastic Lead Time", Operations Research, Vol. 27

[20]. Kim, Joon-Seok and Benjaafar, "Is the (Q,R) Model appropriate for Production-Inventory Systems?" University of Minnesota

[21]. Benton and Park, 1996, "A classification of literature on determining the lot size under quantity discounts", European Journal of Operational Research.

[22]. Khouja, 2001, "The effect of large order quantities on expected profit in the single-period model", International Journal of Production Economics

[23]. Guder et al, 1994, "Capacitated Multiple Item Ordering with Incremental Quantity Discounts", The Journal of Operational Research Society

[24]. Amrik, S.S., Ramsay Liz, and Samson Danny, 1993 "JIT Manufacturing: Industry Analysis and a Methodology for Implementation", International Journal of Physical Distributions and Logistics Management

[25]. Sahay and Sanjay Mohapatra (2001) "Technology as A Tool for Turn around: A Case Case of Scooter India Limited", Journal of Case Research ,Volume III ,Issue 1, pp 1-31.

[26]. Krishna Kumar and Ritu Srivastava (2001),Management Case-Scooters India Limited"Journal of DSpace at Indian Institute of Management, Kozhikode ,Vol. 26, No. 2, pp 1-14. 